\title{
Mean platelet volume measurement protocol should be standardized for diabetic retinopathy
}

\author{
Esra Ayhan Tuzcu • Secil Arica • Nilufer Ilhan • \\ Mutlu Daglıglu • Mesut Coskun • Ozgur Ilhan • \\ Ihsan Ustun
}

Received: 27 September 2013 / Accepted: 1 October 2013 /Published online: 15 October 2013

(C) Springer-Verlag Berlin Heidelberg 2013

\section{Dear Editor:}

In our manuscript, the sentence, "Mean platelet volume is a parameter indicating platelet activation and function," was based on the literature [1-3]. The purpose of our study was to identify the risk for diabetic retinopathy (DR) using complete blood count, which is routinely used because it is a simple and inexpensive test.

\author{
E. A. Tuzcu $(\bowtie) \cdot$ N. Ilhan $\cdot$ M. Dagloglu $\cdot$ M. Coskun $\cdot$ O. Ilhan \\ Department of Ophthalmology, Mustafa Kemal Universty Medical \\ Faculty, Hatay, Turkey \\ e-mail: drayhant@hotmail.com \\ N. Ilhan \\ e-mail: niluferilhan@gmail.com \\ M. Daglioglu \\ e-mail: mutluaysen@hotmail.com \\ M. Coskun \\ e-mail: drmesutcoskun@hotmail.com \\ O. Ilhan \\ e-mail: drozgur9@yahoo.com

\section{S. Arica} \\ Deparment of Family Medicine, Mustafa Kemal Universty Medical \\ Faculty, Hatay, Turkey \\ e-mail: secilgunher@hotmail.com \\ I. Ustun \\ Department of Endocrinology and Metabolism Unit, Mustafa Kemal \\ Universty Medical Faculty, Hatay, Turkey \\ e-mail: iustun@yahoo.com
}

As the authors mentioned, light transmission aggregometry (LTA) is the best test to indicate platelet function [4]. However, LTA is time-consuming and challenging, and it must be supervised by an expert that several analytic and para-analytic changes. In addition, LTA is only available at specialized laboratories [4]. Beyan et al. mentions that although it implicitly shows the hemostatic function of platelets, LTA isn't routinely used; it is also a very expensive test [5].

In our study, the blood samples were placed into dipotassium ethylenediaminetetraacetic acid (EDTA) tubes. The complete blood count was performed using an automated hematology analyzer (CELL-DYN 3700, Abbott Diagnostics, Abbott Park, IL, USA). All blood samples are evaluated within $60 \mathrm{~min}$ of the blood sampling.

\section{References}

1. Bancroft AJ, Abel EW, Mclaren M, Belch JJF (2000) Mean platelet volume is useful parameter: A reproducible routine method using a modified coulter trombocytometer. Platelets 11(7):379-387

2. Kim SW, Ryu GH, Lee I, Koh JJ, Min BG, Lee HK (1995) Adhered platelet morphology in diabetes mellitus. Diabetes Metab 21(1):50-53

3. Vinik AM, Macagni A (2001) Platelet dysfunction in type 2 diabetes. Diabetes Care 24(8):1476-1485

4. Cattaneo M (2009) Light transmission aggregometry and ATP release for the diagnostic assessment of platelet function. Semin Thromb Hemost 35:158-167

5. Beyan C, Kaptan K, Ifran A (2006) Platelet count, mean platelet volume, platelet distribution width, and plateletcrit do not correlate with optical platelet aggregation responses in healthy volunteers. J Thromb Thrombolysis 22:161-164 